\title{
PEKERJAAN LUAR USAHATANI (KASUS RUMAH TANGGA PETANI GUREM DI JAWA)
}

\author{
OFF FARM EMPLOYMENT \\ (THE CASE OF PEASANT FAMILY IN JAVA)
}

Ken Suratiyah

Staf Pengajar Jurusan Sosial Ekonomi, Fakultas Pertanian UGM

\begin{abstract}
Small farmer's household never deppend on on-farm income, they must to get other income sources by allocating their family labour as must as possible.

Although they are small farmers, they still regard their job is being farmer and the other off-farm activities just as part time jobs. Family labour allocation on offfarm activities is about four times then on-farm, the off-farm's share to household income are $60,31 \%$.

By off-farm activities household farmer welfare level increase from poverty level to become wealthy level or not be poor level. The fact is show that off-farm activities to become more important for small farmer's household.
\end{abstract}

\section{PENDAHULUAN}

Dari tahun ke tahun kesempatan kerja di pertanian semakin kecil, hal ini antara lain disebabkan oleh (1) adanya kompetisi dalam penggunaan lahan dari lahan pertanian ke non pertanian akibat dari laju pertumbuhan penduduk yang cukup tinggi, kebutuhan perumahan dan perkantoran serta keperluan pembangunan yang lain (2) penggunaan teknologi mekanis pada pengolahan tanah dan penyiangan (3) sistem tanam serempak yang diikuti dengan panen serempak pula (4) sistem tanam dan panen secara borongan, hal ini mengakibatkan petani berlahan sempit tergeser dalam memperoleh peluang kerja di sektor pertanian.

Jika laju pertumbuhan penduduk yang terus meningkat tidak diikuti dengan pertambahan luas lahan maka tekanan penduduk terhadap lahan semakin besar. Sebagai akibatnya rata-rata pemilikan lahan menjadi semakin sempit dan jumlah petani gurem menjadi semakin banyak. Sebagai akibat lanjutan banyak anggota rumah tangga tani yang mencari pekerjaan di luar sektor pertanian, walaupun mereka tetap masih mengerjakan usahataninya.

Usahatani lahan sempit tidak lagi mampu sebagai satu-satunya sumber pendapatan, di samping sifat kegiatan pertanian yang musiman, rendah pendapatan dan mengandung resiko, itu semua menyebabkan petani harus mempunyai berbagai sumber pendapatan untuk memenuhi kebutuhan rumah tangga.

Salah satu aset yang masih bisa dikuasai oleh rumah tangga tani adalah tenaga kerja keluarga. Petani di perdesaan yang pada umumnya tergolong miskin akan selalu mengupayakan agar bisa mengalokasikan tenaga kerja keluarga dengan sebaik baiknya sehingga bisa mendatangkan nafkah bagi seluruh anggota rumah tangga. Bagi rumah tangga tani yang miskin semua tenaga kerja yang ada harus sanggup dan mau bekerja demi untuk mempertahankan kelangsungan ekonomi rumah tangganya. 
Dengan profesi ganda yaitu masih mengerjakan usahatani tetapi juga bekerja di luar usahatani maka rumah tangga petani harus mampu membagi waktu supaya tidak ada kegiatan yang diterlantarkan tetapi total penghasilan yang diperolehnya tinggi.

Dari uraian tersebut timbul pertanyaan :

a). apa saja jenis kegiatan luar usahatani

b). berapa besar curahan waktu pada kegiatan luar usahatani

c). berapa sumbangan pendapatan luar usahatani terhadap total pendapatan rumah tangga tani

d). bagaimana tingkat kesejahteraan RT petani yang melakukan profesi ganda

Untuk menjawab pertanyaan tersebut dirangkum dan dianalisis empat hasil penelitian sejenis yang telah dilakukan di Kecamatan Ngemplak Sleman tahun 1995/1996, di Kecamatan Sumowono Semarang tahun 1996/1997, di Kecamatan Sanden Bantul tahun 1998/1999 dan di Kecamatan Maos Cilacap tahun 1999/2000, keempatnya adalah sekripsi mahasiswa bimbingan penulis sendiri.

Dari rangkuman dan analisis tersebut diharapkan dapat menggambarkan variasi antar daerah perkembangan peranan kegiatan luar usahatani sehubungan dengan curahan waktu serta kontribusinya terhadap pendapatan rumah tangga dan tingkat kesejahteraan.

\section{METODE PENELITIAN}

1. Pemilihan lokasi/daerah penelitian

a. Penelitian di Kabupaten Sleman dilakukan di Kecamatan Ngemplak dengan alasan terluas areal padi sawahnya, sehingga ketergantungan pada kegiatan luar usahatani kecil.

b. Penelitian di kabupaten Semarang dilakukan di Kecamatan Sumowono dengan alasan dekat dengan kota sehingga banyak variasi kegiatan luar usahataninya.

c. Penelitian di Kabupaten Bantul dilakukan di Kecamatan Sanden dengan alasan terbanyak desa miskinnya, sehingga ketergantungan pada kegiatan luar usahatani besar.

d. Penelitian di Kabupaten Cilacap dilakukan di Kecamatan Maos dengan alasan produktivitas padi tertinggi, sehingga ketergantungan pada kegiatan luar usahatani kecil

\section{Penelitian petani/responden}

Di semua penelitian pemilihan petani.responden secara Random sampling pada petani yaitu orang yang menggarap lahan tanpa melihat status lahannya.

\section{KEADAAN RUMAH TANGGA TANI}

Pada umumnya dari segi pendidikan formal kepala rumah tangga petani termasuk rendah setara dengan pendidikan sekolah dasar. Dengan pendidikan yang rendah tanpa ketrampilan dan pengalaman maka petani akan kesulitan dalam meraih peluang kerja di luar usahatani. Akibatnya mereka hanya bisa terjun dan menekuni pekerjaan-pekerjaan yang tidak memerlukan syarat pendidikan kusus dan biasanya berpenghasilan rendah pula. 
Tabel 1. Identifikasi Kepala Rumah Tangga Tani di Daerah Penelitian

\begin{tabular}{|l|c|c|c|c|}
\hline \multicolumn{1}{|c|}{ Uraian } & $\begin{array}{c}\text { Ngemplak } \\
\text { Sleman }\end{array}$ & $\begin{array}{c}\text { Sumawono } \\
\text { Semarang }\end{array}$ & $\begin{array}{c}\text { Sanden } \\
\text { Bantul }\end{array}$ & $\begin{array}{c}\text { Maos } \\
\text { Cilacap }\end{array}$ \\
\hline 1. Umur & 93,33 & 95 & 88,33 & 86,70 \\
a. Produktif (\%) & 6,67 & 5 & 11,67 & 13,30 \\
b. Tidak Produktif (\%) & & & & \\
\hline 2. Pendidikan formal & 66,70 & 47,50 & 47,50 & 60 \\
a. Setara SD (\%) & 25 & 25 & 37,50 & 21,66 \\
b. Setara SLTP (\%) & 8,30 & 27,50 & 15 & 18,34 \\
c. Setara SLTA (\%) & & & & \\
\hline 3. Rerata Jumlah & 4 & 6 & 5 & 5 \\
Anggota rumah tangga (orang) & & & & \\
\hline 4. Penguasaan lahan & 93,30 & 82,50 & 100 & 85 \\
a. <0,5 ha (\%) & 6,70 & 17,50 & - & 15 \\
b. >0,5 ha (\%) & 0,3400 & 0,3957 & 0,0982 & 0,3481 \\
c. rerata (ha) & & \multicolumn{2}{|c|}{} \\
\hline
\end{tabular}

Sumber : analisis data rumah tangga tani

Dari tabel 1 tampak bahwa ada keseragaman antar daerah yang menegaskan bahwa sebagian besar petani termasuk petani gurem yang rata-rata penguasaan lahanya masih jauh dari 0,5 ha. Dari fakta tersebut jelas bahwa petani tidak bisa menggantungkan hidupnya hanya pada usahataninya saja, petani pasti harus mencari peluang kerja di luar usahataninya. Dari tabel 1 tampak pula bahwa sebagian besar petani berpendidikan rendah, keadaan tersebut akan menjadi kendala mana kala petani harus bersaing dalam rangka memperebutkan kesempatan kerja di luar usahataninya. Di samping pendidikan kendala lain adalah pengalaman kerja. Pada umumnya mereka kurang pengalaman karena dari tahun ke tahun mereka hanya bekerja di usahatani seperti apa yang dikerjakan oleh orang tuanya (turun temurun).

Satu hal yang perlu diperhatikan dalam meraih peluang kerja di luar usahatani adalah Perubahan mental. Seorang petani sekecil apapun (petani gurem) adalah orang yang bekerja mandiri, memutuskan sendiri, bekerja di lahan sendiri tanpa terlihat peraturan jam kerja dan sebagainya. Manakala dia harus memasuki pekerjaan formal (pekerja pabrik misalnya) dia akan kesulitan menyesuaikan diri dengan peraturan dan perintah-perintah yang mengikat, dia bukan lagituan di atas tanahnya sendiri.

Walaupun petani termasuk ke dalam golongan petani gurem namun demikian jika mereka ditanya apa pekerjaan pokoknya adalah petani sedangkan pekerjaan sampingan di luar usahataninya (off farm) sangat bervariasi antara lain : buruh bangunan, buruh angkut, tukang kayu, tukang batu, tukang pijat, bakulan (dagang kecil-kecilan), makelar dan sebagainya.

Dari sekian macam pekerjaan luar usahatani maka dagang/bakulan adalah dominan, hal ini disebabkan karena tidak memerlukan modal yang tinggi (skala kecil, warung) tidak memrlukan keahlian kusus dan yang penting adalah mandiri. Sebagai pedagang kecil/bakul mereka bebas menentukan sendiri kapan kulakan (belanja), berapa jumlahnya dan apa saja macamnya. Hal ini sesuai dengan pekerjaan pokok mereka yaitu petani yang mandiri, tuan di atas usahataninya sendiri. 
Tabel 2. Distribusi Rumah Tangga Tani Atas Dasar Pekerjaan Luas Usahatani di Daerah Penelitian

\begin{tabular}{|l|c|c|c|c|}
\hline \multicolumn{1}{|c|}{ Uraian } & $\begin{array}{c}\text { Ngemplak } \\
\text { Sleman }\end{array}$ & $\begin{array}{c}\text { Sumawono } \\
\text { Semarang }\end{array}$ & $\begin{array}{c}\text { Sanden } \\
\text { Bantul }\end{array}$ & $\begin{array}{c}\text { Maos } \\
\text { Cilacap }\end{array}$ \\
\hline l. Dagang/bakulan (\%) & 38,34 & 30 & 6,68 & 23,34 \\
\hline 2. Buruh (\%) & 8,30 & 15 & 41,66 & 41,66 \\
\hline 3. Tukang (\%) & 3,30 & 15 & 18,33 & 5 \\
\hline 4. Lain-lain (\%) & 50,06 & 40 & 33,33 & 30 \\
\hline
\end{tabular}

Keterangan : - tukang (pijgga tani

- buruh (pijit, batu, kayu dsb)

buruh (bangunan, tani, serabutan dsb)

Di samping faktor tersebut, hal ini juga disebabkan karena daerah penelitian adalah daerah yang terbuka, transportasinya lancar, dekat dengan pasar sehingga memungkinkan mereka berusaha, walau hanya kecil-kecilan. Kusus untuk sampingan sebagai numah tangga tani sebagian (33,33\%) mempunyai pekerjaan proporsinya.

\section{CURAHAN WAKTU}

Bagi rumah tangga tani yang tergolong pada petani gurem yang jelas tidak bisa menggantungkan hidupannya dari hasil usahataninya, mereka bekerja merupakan keharusan untuk menjaga kelestarian ekonomi rumah tangga. Mereka akan berusaha memasuki sektor-sektor informal yang berada di sekitar mereka sendiri dan sesuai
dengan human kapitalnya.

Karena walaupun sempit mereka masih menggarap lahan pertanian dan bahkan menggarap sebagai pekerjaan pokok maka mereka mencurahkan waktu ganda baik di usahatani (on farm) maupun di luar usahatani (off farm).

Tabel 3. Rata-rata Curahan Waktu Pada Usahatani Berdasarkan Jenis Kegiatan di daerah Penelitian

\begin{tabular}{|c|c|c|c|c|}
\hline 1. Pesemaian & $\begin{array}{c}\text { Ngemplak } \\
\text { Sleman } \\
\text { (jam/th) }\end{array}$ & $\begin{array}{c}\text { Sumawono } \\
\text { Semarang } \\
\text { (jam/th) }\end{array}$ & $\begin{array}{c}\text { Sanden } \\
\text { Bantul } \\
\text { (jam/h) } \\
\end{array}$ & $\begin{array}{l}\text { Maos } \\
\text { Cilacap } \\
\text { (jam/th) }\end{array}$ \\
\hline 2. Pengolahan tanah & 58,26 & $*$ & - & 31,43 \\
\hline 3. Tanam & 142,64 & 256,41 & - & 64,60 \\
\hline 4. Pemupukan & 34,02 & 25,80 & - & 47,60 \\
\hline 5. Pemeliharaan & 32,28 & 40,49 & - & 86,83 \\
\hline 6. Pemberantasan hama & 303,36 & 696 & - & 229,13 \\
\hline $\begin{array}{l}\text { dan penyakit } \\
\text { 7. Panen }\end{array}$ & 1,36 & 16,72 & - & 22,07 \\
\hline Jumlah & 32,68 & 36,68 & - & 33,30 \\
\hline Luas garapan (ha) & 606,44 & $1.072,10$ & 191,27 & 514,96 \\
\hline Sumber : analisis dat & 0,3400 & 0,3980 & 0,0982 & 0,3480 \\
\hline
\end{tabular}

Keterangan : *) term ruah tangga tani

suk dalam pengolahan lahan 
Dari tabel 3 tersebut nampak bahwa curahan waktu untuk usahatani masih sangat kecil baru berkisar antara 1,5 - 3,0 jam per hari, hal ini bisa dimaklumi karena luas garapan yang sangat terbatas, oleh karena itu rumah tangga petani gurem tersebut mencurahkan sisa waktunya pada kegiatan di luar usahataninya.

Di samping itu juga disebabkan karena kegiatan pada usahatani hersifat musiman dan serentak sehingga sering terjadi pada saat-saat tertentu kegiatan membutuhkan tenaga yang banyak dan bersifat serentak (misal : pengolahan tanah, tanam dan panen) sehingga petani harus melibatkan tenaga kerja luar yang diupah, sedangkan di lain waktu kegiatan bisa ditangani sendiri (misal : pemupukan dan pemeliharaan).

Dengan rata-rata anggota rumah tangga 4-6 orang (lihat tabel), maka jelas masih ada waktu yang bisa dan harus dicurahkan untuk kegiatan nafkah di luar usahatani.

Tabel 4. Rata-rata Curahan Waktu pada Kegiatan Nafkah Luar Usahatani di Daerah Penelitian

\begin{tabular}{|c|l|c|c|}
\hline No & \multicolumn{1}{|c|}{ Uraian } & (jam/tahun) & (jam/hari) \\
\hline 1 & Ngemplak, Sleman & $1.459,83$ & 4,05 \\
\hline 2 & Sumowono, Semarang & $6.979,00$ & 19,38 \\
\hline 3 & Sanden, Bantul & 172,81 & 0,48 \\
\hline 4 & Maos, Cilacap & $1.023,18$ & 2,84 \\
\hline
\end{tabular}

Sumber : analisis data rumah tangga tani

Keterangan : satu tahun 360 hari

Dari tabel 4 tersebut terlihat bahwa curahan waktu rumah tangga bervariasi antar lokasi penelitian hal ini disebabkan oleh adanya variasi jenis pekerjaan di luar usahatani. Curahan waktu di Sumowono Semarang tinggi karena sebagian rumah tangga petani adalah karyawan swasta yang mempunyai jam kerja yang teratur tiap hari, sehingga total per tahunnya menjadi besar.

Jika dibandingkan antara curahan waktu pada usahatani dengan luar usahatani, jelas terlihat bahwa petani tidak lagi hanya tergantung pada usahataninya saja.

Dari tabel 4 juga terlihat ada perbedaan yang menyolok terutama curahan waktu di Sanden Bantul, hal ini disebabkan karena yang mempunyai kegiatan luar usahatani hanya satu orang saja dalam rumah tangga yang bersangkutan (terutama kepala rumah tangga) sehingga waktunya terbatas.

Tabel 5. Rata-rata Total Curahan Waktu Untuk Kegiatan Nafkah di Daerah Penelitian

\begin{tabular}{|c|l|r|r|r|r|}
\hline No & \multicolumn{1}{|c|}{ Uraian } & $\begin{array}{c}\text { Ngemplak } \\
\text { Sleman }\end{array}$ & $\begin{array}{r}\text { Sumowono } \\
\text { Semarang }\end{array}$ & $\begin{array}{c}\text { Sanden } \\
\text { Bantul }\end{array}$ & $\begin{array}{c}\text { Maos } \\
\text { Cilacap }\end{array}$ \\
\hline 1 & Usahatani (jam/th) & 606,44 & $1.072,10$ & 191,27 & 514,96 \\
\hline 2 & Luar Usahatani (jam/th) & $1.459,83$ & 6979,00 & 172,81 & $1.023,18$ \\
\hline 3 & Jumlah (jam/th) & $2.066,27$ & $8.051,10$ & 364,08 & $1.538,14$ \\
\hline 4 & Rata-rata per hari (jam/th) & 5,74 & 22,36 & 1,01 & 4,27 \\
\hline
\end{tabular}

Sumber : analisis data rumah tangga tani

Keterangan: satu tahun 360 hari

Dari tabel 5 tersebut terlihat bahwa di Sumowono rumah tangga petani telah mencurahkan waktu untuk kegiatan nafkah sangat tinggi yaitu 22,36 jam/hari. Dari 6 anggota rumah tangga dengan asumsi setengahnya atau 3 orang yang bekerja 
maka tiap orang telah mencurahkan waktu lebih dari 7 jam per hari, seingga telah melampaui kriteria BPS yang hanya (35-42) jam per minggu.

Keadaan sebaliknya di Sanden Bantul rumah tangga petani belum memenuhi kriteria BPS tersebut sehingga boleh dikatakan bahwa terdapat pengangguran tidak kentara, karena kalau ditanya mereka memang mempunyai pekerjaan dan bekerja tetapi hanya $1 \mathrm{jam} / \mathrm{hari}$ atau $7 \mathrm{jam} / \mathrm{minggu}$, di samping itu anggota rumah tangga yang lain tidak terhitung bekerja.

\section{PENDAPATAN}

Dengan kenyataan bahwa tidak cukup hanya mengandalkan pendapatan dari usahatani saja untuk memenuhi kebutuhan rumah tangganya, menyebabkan petani mencari sumber pendapatan lain di luar usahatani dengan harapan total pendapatan rumah tangga menjadi lebih besar dan iebih sejahtera dari segi ekonomi.

Tabel 6. Rata-rata Pendapatan Rumah Tangga Tani Berdasar Sumbernya di Daerah Penelitian

\begin{tabular}{|c|c|c|c|c|}
\hline Uraian & $\begin{array}{l}\text { Ngemplak } \\
\text { Sleman }\end{array}$ & $\begin{array}{l}\text { Sumawono } \\
\text { Semarang }\end{array}$ & $\begin{array}{l}\text { Sanden } \\
\text { Bantul }\end{array}$ & $\begin{array}{l}\text { Maos } \\
\text { Cilacap }\end{array}$ \\
\hline $\begin{array}{l}\text { 1. Usahatani } \\
\text { (Rp/th) } \\
(\%)\end{array}$ & $\begin{array}{r}754.574 \\
39,31 \\
\end{array}$ & $\begin{array}{r}686.656 \\
35,24 \\
\end{array}$ & $\begin{array}{r}722.900 \\
40,60 \\
\end{array}$ & $\begin{array}{r}1.829 .533 \\
43,61 \\
\end{array}$ \\
\hline $\begin{array}{l}\text { 2. Luar usahatani } \\
\text { (Rp/th) } \\
(\%)\end{array}$ & $\begin{array}{r}1.165 .000 \\
60,69 \\
\end{array}$ & $\begin{array}{r}1.261 .585 \\
64,76 \\
\end{array}$ & $\begin{array}{r}1.057 .500 \\
59,40 \\
\end{array}$ & $\begin{array}{r}2.365 .000 \\
56,39 \\
\end{array}$ \\
\hline $\begin{array}{l}\text { 3. Total } \\
\text { (Rp/th) } \\
(\%)\end{array}$ & $\begin{array}{r}1.919 .574 \\
100\end{array}$ & $\begin{array}{r}1.948 .241 \\
100\end{array}$ & $\begin{array}{r}1.780 .400 \\
100\end{array}$ & $\begin{array}{r}4.194 .533 \\
100\end{array}$ \\
\hline
\end{tabular}

Sumber : Analisis Data Rumah Tangga Tani

Dari tabel 6, terlihat bahwa dominan kontribusi pendapatan luar usahatani terhadap total pendapatan rumah tangga petani di tiga lokasi bahkan hampir sama sekitar $60 \%$. Angka tersebut mempertegas bahwa petani tidak lagi hanya menggantungkan ekonomi rumah tangganya pada usahatani saja. Kenyataan tersebut menunjukkan pula betapa pentingnya lapangan kerja di luar usahatani (off farm activities), karena human capital petani yang terbatas sehingga tidak bisa bersaing di pasar kerja formal maka petani harus bisa menciptakan peluang kerja luar usahatani bagi diri sendiri dan anggota rumah tangganya, sukar kalau bisa memberi kesempatan pula bagi para tetangga atau masyarakat sekelilingnya.

Dari tabel 6 tersebut bisa diartikan pula bahwa kegiatan ekonomi di luar usahatani bisa meningkatkan pendpaatan rumah tangga petani berkisar antara 2,29 sampai 2,8 kali. Namun demikian petani tetap menganggap pekerjaan tersebut adalah sambilan saja.

\section{TINGKAT KESEJAHTERAAN RUMAH TANGGA}

Ada beberapa kriteria untuk menentukan tingkat kesejahteraan rumah tangga, kriteria tersebut berkembang sejak tahun 1997 dengan mengacu pada kriteria BPS pada tiap-tiap kabupaten daerah tingkat dua atau pada tiap-tiap propinsi. Namun demikian karena tulisan ini merangkum empat penelitian sejak tahun 1995/1996 sampai dengan tahun 1999/2000 maka dipakai kriteria kemiskinan Sayogyo untuk perdesaan. Suatu rumah tangga di perdesaan dikatakan tidak miskin jika pendapatan 
perkapita setara dengan di atas $480 \mathrm{~kg}$ nilai tukar beras per tahun. Dari kriteria tersebut maka dapat ditentukan keadaan tingkat kesejahteraan rumah tangga petani di tiga daerah penelitian, dengan standar:

A. Harga beras saat penelitiaan,
1. Ngemplak Sleman
$1995 / 1996$
2. Sumowono Semarang
$1996 / 1997$
3. Maos Cilacap
$1999 / 2000$
4. Sanden Bantul
1988/1999
Rp $400 / \mathrm{kg}$
$\operatorname{Rp} 700 / \mathrm{kg}$
$\operatorname{Rp} 1300 / \mathrm{kg}$
$\operatorname{Rp} 1350 / \mathrm{kg}$

B. Kriteria Sayogyo, untuk rumah tangga perdesaan

1. Miskin jika pengeluaran rumah tangga di bawah $480 \mathrm{~kg}$ nilai tukar beras/kapita/tahun

2. Miskin sekali jika pangan tak cukup di bawah $360 \mathrm{~kg}$ nilai tukar beras/kapita/tahun

3. Paling miskin jika pengeluaran di bawah $240 \mathrm{~kg}$ nilai tukar beras/kapita/tahun

4. Lapisan rumah tangga dengan pengeluaran 360 - $480 \mathrm{~kg}$ nilai tukar beras/kapita/tahun disebut lapisan ambang kecukupan pangan.

Tabel 7. Rata-rata Tingkat Kesejahteraan Rumah Tangga Petani di daerah Penelitian

\begin{tabular}{|l|r|r|r|r|}
\hline $\begin{array}{l}\text { Ngemplak } \\
\text { Sleman }\end{array}$ & $\begin{array}{c}\text { Sumawono } \\
\text { Semarang }\end{array}$ & \multicolumn{1}{c|}{$\begin{array}{c}\text { Sanden } \\
\text { Bantul }\end{array}$} & \multicolumn{1}{c|}{$\begin{array}{c}\text { Maos } \\
\text { Cilacap }\end{array}$} \\
\hline $\begin{array}{l}\text { (orang) } \\
\text { 2. Pendapatan dari }\end{array}$ & 4 & 6 & 5 & 5 \\
Usahatani & & & & \\
a. (Rp/th) & 754.574 & 686.656 & 722.900 & 1.829 .533 \\
b. (Rp/kap/th) & $188.643,50$ & $114.442,60$ & 144.580 & $365.906,60$ \\
c. (kg/kap/th) & 471,60 & 163,48 & 107,09 & 215,23 \\
d. Kriteria & Miskin & Paling miskin & Paling miskin & Paling miskin \\
\hline 3. Pendapatan total & & & & \\
a. (Rp/th) & 1.919574 & 1.948 .241 & 1.780 .400 & 4.194 .533 \\
b. (Rp/kap/th) & $479.893,50$ & $324.706,83$ & 356.080 & $838.906,60$ \\
c. (kg/kap/th) & $1.193,73$ & 463,86 & 263,76 & 493,47 \\
d. Kriteria & Tdk.miskin & Miskin*) & Miskin sekali & Tidak miskin \\
\hline
\end{tabular}

Sumber: analisis data rumah tangga tani

Catatan *) termasuk lampiran ambang kecukupan pangan

Dari tabel 7 terlihat bahwa jika rumah tangga petani hanya mengandalkan usahataninya saja maka rumah tangga petani Ngemplak termasuk golongan miskin, petani Sumowono tergolong miskin sekali demikian pula rumah tangga petani Maos Cilacap.

Namun demikian dengan pekerjaan di luar usahatani maka level kesejahteraan rumah tangga petani bisa meningkat menjadi golongan tidak miskin kecuali rumah tangga petani di Sumowono Semarang, mereka termasuk lapisan ambang kecukupan pangan.

Dari tabel 7 tersebut jelas terlihat peranan pekerjaan di luar usahatani dalam rangka meningkatkan kesejahteraan ekonomi rumah tangga petani. Dengan berjalannya waktu semakin sempit lahan garapan maka akan semakin besar peran pekerjaan luar usahatani. Satu-satunya jalan mengingat bahwa sumberdaya yang 
masih bisa dikuasai adalah tenaga kerja keluarga maka rumah tangga tani harus bisa memperbanyak curahan waktu ke luar usahatani dengan cara mengerahkan semua tenaga kerja keluarga yang ada, sepanjang mampu dan ada peluangnya.

\section{PENUTUP}

Petani gurem tidak mungkin lagi hanya menggantungkan diri pada usahataninya saja. Untuk menjaga kelangsungan ekonomi rumah tangganya, mereka harus bisa memanfaatkan pekerjaan di luar usahataninya sehingga pendapatan gabungan yang akan diperolehnya menjadi lebih besar.

Satu-satunya sumberdaya manusia yang bisa dikuasai dan dikendalikan olehnya adalah tenaga kerja keluarga oleh karena itu untuk meningkatkan pendapatan dalam rangka menjaga kelangsungan ekonomi rumah tangga maka semua potensi tenaga kerja tersebut harus bisa dimanfaatkan. Namun demikian karena pada umumnya human capitalnya sangat terbatas maka mereka hanya bisa memasuki kegiatan kerja yang terbatas pula di sektor informal yang pada akibatnya pendapatannya rendah.

Kegiatan luar usahatani memberikan kontribusi yang sangat berarti pada pendapatan rumah tangga (sekitar 60\%) dan pada tingkat kesejahteraannya, walaupun dengan kegiatan tersebutpun masih ada rumah tangga tani yang tetap tergolong miskin sekali. Kenyataan tersebut lebih menegaskan perlunya penyediaan peluang kerja bagi rumah tangga petani tersebut tentu saja yang sesuai dengan keadaan mereka yang serba terbatas tersebut, di samping menanamkan pengertian agar mereka tidak menganggap aktivitas ekonomi di luar usahtani hanya sekedar sampingan saja, hal ini penting untuk mengantisipasi kemungkinan-kemungkinan yang akan terjadi di kemudian hari.

\section{DAFTAR PUSTAKA}

Effendi, Tadjuddin Noer (1995), Sumber Daya Manusia, Peluang Kerja dan kemiskinan PT. Tiara Wacana Yogya.

Gunawan, Bakti (1998), Kajian Ekonomi Rumah Tangga Tani di Desa Miskin di Kabupaten Bantul, Skripsi UGM Yogyakarta.

Marwanti, Sri (1992), Kerja Luar Usahatani Oleh Rumah Tangga Tani padi di Kecamatan Tawangsarí Sukoharjo, Tesis UGM Yogyakarta.

Mubyarto (1987), Kesempatan kerja di Pedesaan Indonesia Dalam prospek Pedesaan, P3PK UGM Yogyakarta.

Pratiwi, Ethic Setya B (2000), Faktor-Faktor Yang Mempengaruhi Curahan Tenaga Kerja Keluarga Tani Di Luar Usahatani Padi Sawah di Kabupaten Cilacap, Skripsi INSTIPER Yogyakarta.

Sayuti, Muhammad (1995), Pekerja Luar Usahatani Ditinjau dari Curahan Waktu Dan Pendapatan Petani Padi Sawah Di Kabupaten Sleman, Skripsi INSTIPER Yogyakarta.

Shand, RT (1986), Aff-Farm Emplayment in The Rural Development of Rural Asia, Caubera : National Center for Development Studies, ANU.

Sidik, Muhammad (1991), Alokasi Waktu Kerja Dan Pendapatan Rumah Tangga Tani: Studi Kasus di 4 Desa di kabupaten Lombok Tengah, BPPS UGM jilid 4 No.3.

Suratiyah, Ken (1997), Konsep-Konsep Kegiatan Off-Farm Populasi Vol. 5 No. I Tahun 1994.

Susanti, Ambar (1997), Hubungan Curahan Jam Kerja Kepala Keluarga Pada Usahatani Dan Luar Usahatani Dengan Pendapatan Rumah Tangga Tani, Studi Kasus di sumowono Semarang, Skripsi INSTIPER Yogyakarta. 